\title{
E-RESOURCES FOR PUBLIC LIBRARIES: A PROPOSAL IN THE CONTEXT OF NATIONAL MISSION ON LIBRARIES
}

\section{KAPIL SINGH HADA}

Librarian, Shri Ratanlal Kanwarlal Patni Girls' College, Kishangarh (Rajasthan), India

Public Libraries should provide e-information to their community/readers, in the form of e-books, e-journals, e-paper, which information is available in electronic form. National Mission on Libraries provides financial support to public libraries, for subscribing e-resources for user need. NML is also created National Virtual Library of India (NVLI), setting up of NML Model Libraries, Quantitative \& Qualitative Survey of Libraries and Capacity Building. Eresources are very important part of any library, but it is not available in public libraries today. The present paper brief information about the e-resources, genesis of e-resources, advantages, disadvantages over the print resources, and also discusses compare study of both form of information. The present paper also gave information a comprehensive list of e-resources which useful for public libraries and their users, and also discussed impact of e-resources on public libraries service.
\end{abstract}

KEYWORDS: E-Resources, E-Information, ICT's, National Mission on Libraries \& Public Libraries

Received: Jun 06, 2017; Accepted: Jun 28, 2017; Published: Oct 28, 2017; Paper Id.: IJLSRDEC20171

\section{INTRODUCTION}

\section{National Mission on Libraries}

National Mission on Libraries has been set up by Ministry of Culture, Government of India, on $4^{\text {th }}$ May, 2012 in pursuance of National Knowledge Commission recommendations for stained attention for development of Libraries and Information Science Sector. National Mission on Libraries set up four working groups and after deliberating on the recommendations of the working groups formulated the scheme "National Mission on Libraries (NML) - up gradation of libraries providing service to the public". The scheme consists of four components.

Creation of National Virtual Library of India (NVLI); Setting up of NML Model Libraries; Quantitative \& Qualitative Survey of Libraries; Capacity Building.

Public libraries in India will soon go digital. The government is planning to digitize reading material in different languages and launch the National Virtual Library of India. President Pranab Mukherjee on Monday launched massive scheme, to upgrade public libraries in India, as recommended by the National Knowledge Commission. The National Mission on Libraries, expected to cost Rs $400 \mathrm{cr}$, will develop 35 central libraries and 35 district libraries, as model libraries. Over 600 libraries will also get network connectivity. Mukherjee said "I understand that it will acquire the digitized information available with various Government Departments and other Non - Government Organizations, build a comprehensive data base for this information and present it as a user-friendly service including multilingual services." These model libraries will have subscription based ejournals and e-books as services through a VPN service provided by the National Informatics Center. Libraries will 
conduct a holistic professional and personal development programme, for Library professionals through capacity building, said Mukherjee. President Pranab Mukherjee, on Monday launched the Rs 400-crore National Mission on Libraries (NML), in New Delhi. Appreciating the Ministry of Culture for taking the initiative for long-term focus, on the development of libraries, he lauded the efforts to "revamp, re-energize and reorient the library and information service sector". The mission has been set up in keeping with the recommendations made by the PM-backed National Knowledge Commission. "Digital libraries open up the possibility of far more flexible and coherent multimedia collections that are both fully searchable and browsable, in multiple dimensions. As each generation becomes more in tune with the Internet, their desire to retrieve information as quickly and easily as possible has increased. Finding information by simply searching the Internet is considered much easier and faster, than reading an entire book. I am confident that, this initiative will largely facilitate the Internet savvy people, in making maximum use of library resources," he said.

\section{What are E-Resources}

Due to change in ICT's the methods of collection, storage, organization and dissemination of information is also changing. Electronic publishing is one of the important developments of information technology. To satisfy the information needs of the users, library keeps various resources. E-Resources are essential part of any library. Electronic resources are invaluable tools which harmonize print-based resources traditional library. An increasingly important function of any library today is the provision of information in electronic formats. E-Resources are available in various digital media, such as CD-ROM, DVD, Online Databases and digital Achieves, Electronic information contains originally published information in digital format or information originally published in print and made available electronically.

"Electronic resources" refer to those materials that require computer access, whether through a personal computer, mainframe, or handheld mobile device. They may either be accessed remotely via the Internet or locally. The most frequently encountered types are: E-journals; E-books; Full-text (aggregated) databases; Indexing and abstracting databases; Reference databases (biographies, dictionaries, directories, encyclopedias, etc.); Numeric and statistical databases; E-images; E-audio/visual resources.

\section{Genesis of E-Resources}

E-resources are began access in the library development of Machine Readable Cataloguing-MARC-I, it is developed by Library of Congress, USA. The MARC-I was developed and created codes for place of publication, language and publisher, computer software was designed and procedures were developed and documented. It is also further improved it named was MARC-II format in March 1967 and it is based on feedback from libraries that participated in the pilot project of MARC-I. MARC-II was designed to serve as a communication or exchange medium. It is foundation for libraries to share bibliographic data in the future. Fredrick G. Koligour, in 1967 established the Ohio College Library Centre (OCLC), which was the first computerized library network. In 1971 OCLC introduced shared cataloguing database, it was called World Cat, and it was implemented in Ohio between 54 academic libraries. It is the beginning the online cataloguing systems and shares their records bibliographic records. OPAC stands for Online Public Access Catalogue, it is developed in 1975, Ohio State University Libraries installed computer terminal, to search the catalogue by author, title, author and title, call number and LC subject heading, and Online catalogues is replaced card catalogue in libraries and it has also integrated with acquisition an circulation process. Web based catalogue and web OPAC is define the electronic representations of information about the products and/or services. It is also used in online journal, bibliographical databases and other online information. Further development and invent in Information IT/CSE and development in the 
form of Databases. The database is an organized collection of data for one or more process usually in digital form. The databases include as periodicals, indexes and abstracts, directories, encyclopedias, and other references, and it is also provided search facilities by subjects, type and title with Boolean logic. There are few type databases viz bibliographical databases, CD-ROM databases, Online Databases, Web based databases. In Bibliographical databases, it is an organized digital collection of references to published literature, journals, newspaper articles, conference proceedings, seminar volumes, reports, governments publications, book etc. The first database- software was named is Dialog Invented Online in 1966. In 1969, System Development Corporation (SDC) created a retrieval program for National Library of Medicine ELHILL, which was precursor to MEDLINE. After these further development of Computer bibliographical database and it was further steps towards electronic resources. CD-ROM database is also known as Compact Disk-Read Only Memory, it is a typical disk capable of storing a large amount up to 1GB. The first commercially available CR-ROM database is Library Corporation's BiblioFile. Online databases are added to full text articles. It was used in mid 1980's. The online searching is only done by TELNET protocol and private for profit network not on internet. WEB based databases is an organized listing of web pages. In these databases publishing, sharing, controlling on the web and by the web, and also improved and it called e-journals, e-book, and other e-type information sources are available present time.

\section{Definition of Electronic Resources}

Electronic resources can be defined as the scholarly publication that can be accessed via electronic transmission. These are Web based, available $24 * 7$, accessible to multiple concurrent users, more current than print, support distance education, reach to remote and have no constraint to time and location. E-resources an increasingly important component of the collection-building activities of libraries, they main concentrates mainly in academic and research library purposes, but nonetheless will be of high value to many types of libraries.

Gurudev Sing (2011) Stated That, e-resources means the publication and dissemination of information by electronic means, especially by the use of optical disk formats such as CD-ROM's and networking, other options can include the use of electronic databases, video-texts, e-mail and e-newsletter.

An E-Resource is an Electronic Information Resource that can be accessed on the web, on or off campus. User can get the information what he or she want, when it is needed, explaining in border context, an e-resources is collection of digital content delivery to the user via the internet (Shukla, 2010).

\section{Advantage \& Disadvantages of E-Resources}

\section{Advantages of E-Resources}

- Accessible: Can be accessed from any computer on campus and usually any computer off campus, any time of the day or night, so there is no need to make a trip to the library

- Easily searchable: Each journal can be searched quick and easy often through the complete full text of articles and via online index

- Speed: Articles/issues appear online before printed version is available

- Interactive: Rapid turnaround time means articles can be read, commented by the readers, amended quickly and greater feedback thru the web

- Links: Hypertext format should be exploited and links to related articles, information on other web sites, stable 
URLs for individual articles and email alerts when latest issue loaded.

- Added Value: Advantages taken on the web is to add value by using animation, virtual reality and interactive mathematical charts.

- Inexpensive: Savings can be made over printing costs, distribution costs and extra costs by new features.

- Flexibility: E-journals evolved quickly. They are not tied to a format, printer, and distribution network

\section{Disadvantages of E-Resources}

- Difficulty reading computer screens:

- limitations of computer monitor

- $\quad$ read information in the screen

- $\quad$ Often not included in indexing and abstracting services

- Search engines ignores PDF files

- Format that a large proportion of e-journal use, it is available in different form like PDF, text formats, HTML, so it is very difficult to users to familiar with the latest technology.

- Different standards currently in use.

- Violation of copyright acts

\section{The Differences between Electronic and Paper Document}

- The magnitude of electronic data is way larger than paper documents Variety of electronic documents is larger than paper documents;

- Electronic documents contains attributes lacking in paper documents;

- $\quad$ Electronic documents are more efficient than paper documents ;

- The structure of electronic documents may reach complexity absent from paper documents;

- Electronic documents are more persistent and more difficult to destroy than paper documents;

- Electronic documents change faster, more frequently and easier than paper documents;

- Electronic documents last longer than paper documents;

- The redundancy in electronic documents is higher than in paper documents;

- An electronic data is more likely to be created by several individuals than a paper document;

- Electronic documents may be created by electronic means while paper documents are created by humans;

- Electronic discovery requires support of an infrastructure that paper discovery has never needed 


\section{User Category of Public Library}

The public library has to aim to serve all citizens and groups. An individual is never too young or toll old to use a library.

The public library has the following potential groups.

- People at all ages and at all stages of life

- Children; Young Adults; Adults

- Individuals and groups of people with special needs

- People from different cultures and ethnic groups including indigenous people; People with disabilities, e. g. blind and partially sighted, hearing impaired; Housebound people; Institutionally confined people, e.g. in hospitals, prisons

- Institutions within the wider community networks

- Educational, cultural and voluntary organization and groups in the community; The business community; The governing body of the parent organizations e.g. local authority;

As resources are limited in even the wealthiest society it is not always possible to serve all users the same level. The library must establish priorities based on an analysis of user need and related to their access to alternative services.

\section{Types of Resources in Public Library}

The following categories of library materials may be represented in a typical public library, although this list is not exhaustive:

fiction and non-fiction for adults, young adults and children; reference works; access to databases; periodicals; local, regional and national newspapers; community information; government information, including information by and about local administrations; business information; local history resources; genealogical resources; resources in the primary language of the community; resources in minority languages in the community; resources in other languages; music scores; computer games; toys; games and puzzles; study materials.

The required information services by users of public libraries are mainly divided given below categories:

- Agriculture Information: Weather, seeds, implements, new methods, instruments, equipment, technology, pesticides, animal husbandry etc.

- Educational Information: List of educational institutions, programmes of studies, advertisements, announcements etc

- Educational and Employment: Competitive examinations and admission process

- Health Care Informations: Hospitals, health centers, specialties, health policies and preventive medicine etc.

- Information on Local History: Account on local history of different aspects

- Public Information: Various products and services 
- Public Policy Information: Government programmes, policies, schemes, public grievances, civil rights and duties

- Other Information: other information services not covered by the above.

In general way the given below subject related e-resource should be available in Public Libraries in local language.

Table 1: Different E-Resources in Hindi and English Languages for Public Libraries

\begin{tabular}{|c|c|c|}
\hline Education Related & Employment Related & Career Counseling Related \\
\hline $\begin{array}{l}\text { http://www.ncert.nic.in } \\
\text { http://hi.wikipedia.com } \\
\text { http://www.ignou.ac.in/webhindi/index.htm } \\
\text { http://hi.wikibooks.org/ } \\
\text { http://www.books.hindikhoj.com/?catid-29 }\end{array}$ & $\begin{array}{l}\text { http://www.rogarsamachar.gov.in } \\
\text { http://www.rogaraurnirrman.mp.gov.in } \\
\text { http://www.naukri.com } \\
\text { http://www.freshers.com } \\
\text { http://www.shine.com }\end{array}$ & $\begin{array}{l}\text { http://www.careersalah.com } \\
\text { http://www.careerdisha.org } \\
\text { http://career7india.com } \\
\text { http:://www.career360.org }\end{array}$ \\
\hline Medicine Related & Hindi Directories And Search Engines Related & Astrology Related \\
\hline $\begin{array}{l}\text { http://www.sehtnama.mal.iitk.ac.in } \\
\text { http://www.tradiotionalmedicine.agoodplace4al } \\
\text { 1.com } \\
\text { http://ayurvedaintro.wordpress.com }\end{array}$ & $\begin{array}{l}\text { http://hi.wikipedia.org/wiki } \\
\text { http://www.gurujit.com/hi } \\
\text { http://www.google.com/Top/World/Hindi } \\
\text { http://www.shabdkosh.cim } \\
\text { http://www.aksharamala.com/hindi/e2h/ }\end{array}$ & $\begin{array}{l}\text { http://www.hindihyotish.com } \\
\text { http:webduiniya.com/religion/astrology/raas } \\
\text { hi/ }\end{array}$ \\
\hline Manoranjan Related & Business Related & Religion Related \\
\hline $\begin{array}{l}\text { http://www.funnyhinijokes.com } \\
\text { http://www.lyrisindia.net } \\
\text { http://www.amarujala.com/jokes/default.asp } \\
\text { http://hindi-sms.com }\end{array}$ & $\begin{array}{l}\text { http:hindimoneycontrol.com/ } \\
\text { http://www.josh18.com/business.html } \\
\text { http://www.mynowbusiness.org/hindi } \\
\text { http://www.moltol.in } \\
\text { http://www.webduinia.com/business/ }\end{array}$ & $\begin{array}{l}\text { http://www.aryasamaj.org/newsite } \\
\text { http://hi.wikipedia.org/wiki/ } \\
\text { http://www.thesaileeka.com } \\
\text { http://www.gitapress.org/hindi/homeH.html } \\
\text { http://www.kalyan.org }\end{array}$ \\
\hline Sports Related & Magazine Related & $\begin{array}{c}\text { Computer And Information Technology } \\
\text { Related }\end{array}$ \\
\hline$\frac{\text { http://www.gamesforthebrain.com/hindi }}{\text { http://www.bhaskar.com/sports }}$ & $\begin{array}{l}\text { http://www.sahitykunj.net } \\
\text { http://www.greshsaheli.com } \\
\text { http://www.laghukatha.com } \\
\text { http://www.merisakhi.in } \\
\text { http://www.sahitykunj.net }\end{array}$ & $\frac{\underline{\text { http://www.teach-faq.com/lang/hi }}}{\text { http://www.computerduniya.in/hi }}$ \\
\hline Hindi Samachar Related & Sahitya Related & Museum And Archives \\
\hline $\begin{array}{l}\text { http://www.bhaskar.com } \\
\text { http://.www.jagran.com } \\
\text { http://.www.aajtak.com } \\
\text { http://.www.rashtriyasahara.com/Home.aspx }\end{array}$ & $\begin{array}{l}\text { http://.www. Kavitakosh.org } \\
\text { http://.www. Sahityakunj.net } \\
\text { http://.www.bestghazals.blosspoot.com } \\
\text { http://.www.hindigagan.com }\end{array}$ & $\frac{\text { www.nationalmuseumindian.go.vin }}{\text { www.nationaliarchives.nic.in }}$ \\
\hline Electronic Books Related & Biography Related & Encyclopedia Related \\
\hline $\begin{array}{l}\text { www.questia.com } \\
\text { www.ebrary.com } \\
\text { www.netlibrary.com }\end{array}$ & $\begin{array}{l}\text { http;//www.biography.com } \\
\text { http://zrefer.com }\end{array}$ & $\begin{array}{l}\text { http://britinica.com } \\
\text { http://en.wikipedia.org } \\
\text { www.dekker.com }\end{array}$ \\
\hline Online Book Selling & Science And Technology Related & Databases Related \\
\hline $\begin{array}{l}\frac{\text { www.amazon.com }}{\text { www.abebook.com }} \\
\text { www.bookfindedr.com } \\
\text { www.indianbookcentre.com }\end{array}$ & $\begin{array}{l}\frac{\text { http://www.eseiver.nl }}{\text { http://www.springer.de }} \\
\text { www.blackwellpublishing.com } \\
\text { www.sage.com }\end{array}$ & $\begin{array}{l}\text { www.ncbi.nlm.nih.gov/PubMed } \\
\text { www.blib.org } \\
\text { www.dexigner.com/databases } \\
\text { www.jgate.com } \\
\text { www.oclc.org }\end{array}$ \\
\hline
\end{tabular}

\section{Public Library and E-Resources}

The time has come to establish, expand public libraries services even to the remote area and gave e-information for the development of the rural masses at grass root level. Public libraries functions as an effective instrument in the education, social, cultural, political development of both individuals and community and plays an important role for information industry, providing access to electronic information to their community and can plays a significant role, which can be regarded as the nerve center of the rural area development. It gives opportunities to rural community to participate in e-information effectively and also provide library services to maximum satisfaction, to the rural community. If, electronic resources will be available in the libraries, it will be ease the digital divide in between urban and rural community. E-Resources gave a new dimension to services of public libraries; if the E-Resources will be available in the libraries in the context of National Mission, then it cans the concept of public libraries and modern public libraries transfer and dissemination knowledge instead of information, between persons/communities or groups. It also reduces cost, 
infrastructure, salary of library professional and also increasing the satisfactions of library users. E-resources are available at free cost in each and every public library, so it will be very beneficial for whose enjoy the latest, pinpointed and updated information in their respective field. The mostly and major e-resources are currently are available in English language, so it is very difficult to understand to public library user, so it is the important that, it should be available in Indian and others regional languages, so it will be beneficial and informative to local community to around any public library.

The public libraries face stiff challenges in providing basic library facilities to their clienteles. The public libraries lack in fund and facilities. E-resources are easing the pressure on the finance from Government. If these resources are available at very low cost or totally free, so public library can reduce their expanses on print materials and can diverted to electronic information resources. E-Resources are also increasing efficiency of manpower and improving service quality and gave new dimension of public library in ICT' era. But, it is not an easy task, to provide in-service training, organized workshops and seminar to enhance knowledge towards of e-resources. It provides to public libraries as the extended versions to undertake work of collecting, organizing, disseminating both knowledge and information, in coordination with other institutions and experts, using ICT's and guidance of the management and subject experts, collection information/knowledge under and interrelated system so that duplication is avoided, knowledge is pooled systematically. Public libraries and government agencies should collaborated on government services in areas like public health information, social services, immigration and resources, social services, agriculture related information, emergency, disaster, employment related information, response and other related areas. Public Libraries include service provision within the resource availability of the library, as well as creating an opportunity, for dialogue between libraries and government, that could highlight the issues associated with burden shifting. The e-resources are provided a new range of services like electronic serviced, document delivery service to their users, in ICT's era, Public libraries are gave traditional way services, it is gives an opportunity to public library, to change and step towards in new century.

\section{REFERENCES}

1. www.timesofindia.com (Libraries under Rs 400 cr National Mission on Libraries: February 3, 2014, by Jayadevan P K in Indian Online)

2. Singh, Gurudev (2011). Digital Libraries and Digitization. New Delhi. EssEss Pub.

3. Shukla. S. (2010). Electronic Resources management: What why and how. New Delhi. EssEss Pub.

4. www.wikipedia.org

5. www.ifla.org

6. www.infolibrarian.org

7. www.nkc.ac.in 
